\title{
Sosialisasi Tentang Perlindungan dan Pencegahan Kekerasan dalam Rangka Kampanye 16 Hari Anti Kekerasan Terhadap Perempuan dan Anak
}

\author{
Puri Pramudini ${ }^{1}$, Elferida Sormin ${ }^{2}$, Bernadetha Nadeak ${ }^{3}$, Mita Yesyca ${ }^{4}$, Formas Juitan \\ Lase $^{5}$, Mompang L. Panggabean ${ }^{6}$, Indah Novitasari ${ }^{7}$, Audra Jovani ${ }^{8}$ \\ ${ }^{1}$ Universitas Dr. Muhammmad Hamka \\ $2^{\star}, 3,4,5,6,7,8$ Universitas Kristen Indonesia, Jakarta, Indonesia
}

elferida.sormin@uki.ac.id; bernadetha.nadeak@uki.ac.id; mita.yesyca@uki.ac.id; formas.juitan@uki.ac.id; mompang.panggabean@uki.ac.id; indah.novitasari@uki.ac.id; audra.jovani@uki.ac.id

\begin{abstract}
Abstrak
Kegiatan Pengabdian kepada Masyarakat (PkM) dalam rangka perayaan 16 Hari Kampanye Anti Kekerasan Terhadap perempuan dan Anak yang digagas oleh Pemerintah Daerah Khusus lbukota Jakarta melalui Dinas Pemberdayaan, Perlindungan Anak dan Pengendalian Penduduk (DPPAPP) DKI Jakarta menggandeng sepuluh perguruan tinggi mitra kerjasama yang ada di DKI Jakarta yang salah satunya adalah Universitas Kristen Indonesia (UKI) dan juga lembagalembaga terkait baik negeri maupun swasta. Kegiatan PkM ini diselenggarakan dalam berbagai bentuk, yakni: sosialisasi secara virtual dengan topik-topik yang berbeda namun tetap dalam tema besar yaitu anti kekerasan terhadap perempuan dan anak; dan juga pembuatan video seruan untuk memberantas kekerasan terhadap perempuan dan anak oleh Rektor UKI. Dalam kegiatan PkM ini, Tim UKI memperoleh kesempatan untuk pelaksanaan sosialisasi secara daring untuk empat topik, yakni: 1) Pembelajaran Jarak Jauh (PJJ), enjoy aja; 2) Cerdas Bermedia Sosial;3) Stop Trafficking! Tugas Kita Bersama; 4) Pencegahan Kekerasan di Tempat Publik. Dalam pelaksanaan sosialisasi secara Daring, selain dengan DPPAPP, UKI juga bekerjasama dengan UHAMKA dan STIE IPWIJA. Pelaksanaan sosialisasi berjalan dengan sangat baik diikuti oleh peserta baik yang bergabung secara langsung melalui ruang zoom sekitar 500 orang, dan juga yang menyaksikan melalui youtube channel, Facebook dan Instagram DPPAPP. Kegiatan sosialisasi secara daring ini mendapat respon yang sangat positif dari warga masyarakat, terbukti dari antusiasnya para peserta dalam mengajukan pertanyaan terkait topik yang dibawaka, yang selajutnya ditanggapi dengan sangat detail oleh para narasumber. Rangkaian kegiatan Kampanye 16 Hari Anti Kekerasan Terhadap Perempuan dan Anak juga mendapatkan penghargaan dari lembaga MURI dengan kategori viewers terbanyak, hampir mencapai 1 juta viewers.
\end{abstract}

Kata Kunci:Pengabdian kepada Masyarakat; Kekerasan; Perempuan dan Anak; Sosialisasi

\footnotetext{
Abstract

Community Service Activities (PkM) in the framework of celebrating 16 Days of the Campaign Against Violence Against Women and Children which was initiated by the Government of the Special Capital Region of Jakarta through the DKI Jakarta Empowerment, Child Protection and Population Control Service (DPPAPP) collaborates with ten partner universities in cooperation in DKI Jakarta, one of which is the Christian University of Indonesia (UKI) and also related institutions, both public and private. PkM activities are held in various forms, namely: virtual socialization on
} 


\begin{abstract}
different topics but still on the big theme, namely anti-violence against women and children, and the production of a video calling for eradicating violence against women children by the Rector of UKI. In this PkM activity, the UKI Team had the opportunity to carry out online socialization for four topics, namely: 1) Distance Learning (PJJ), just enjoy it; 2) Smart Social Media; 3) Stop Trafficking! Our Common Duty; 4) Prevention of Violence in Public Places. In implementing online socialization, besides DPPAPP, UKI also collaborates with UHAMKA and STIE IPWIJA. The implementation of the socialization went very well, attended by participants, both who joined directly through the zoom room of about 500 people, and also those who watched through the YouTube channel, Facebook, and Instagram DPPAPP. This online socialization activity received a very positive response from the community, as evidenced by the enthusiasm of the participants in asking questions related to the topic being discussed, which were then responded to in great detail by the speakers. The 16 Days Anti Violence Against Women and Children Campaign series also received an award from the MURI institution with the most viewers category, nearly reaching 1 million viewers.
\end{abstract}

Keywords: Community service; Violence; Women and Children; Socialization

\section{PENDAHULUAN}

Bangsa yang merdeka dan maju adalah bangsa yang memiliki generasi yang kuat pintar dan tangguh. Masa depan suatu bangsa akan tercermin dalam pembentukan karakter generasi penerus bangsa itu sendiri. untuk mewujudkan yang cerdas, kuat dan generasi tangguh itu dimulai dari pendidikan yang mengakar pada budaya suatu bangsa. Pendidikan akan diberikan sedini mungkin kepada setiap anak sehingga terciptanya satu generasi karakter dan penerus yang cerdas. Anak-anak adalah bagian yang tidak terpisahkan dari keberlangsungan hidup manusia dan keberlangsungan hidup berbangsa dan bernegara. Di dalam peraturan perundang-undangan, anak memiliki peran strategis yang secara eksplisit menyatakan bahwa negara menjamin hak setiap anak untuk hidup, tumbuh, dan berkembang serta melindungi dari kekerasan dan diskriminasi (Suryamizon, 2017).
Pendidikan terhadap anak diberikan baik secara formal maupun informal. Secara formal ditempuh melalui kegiatan pembelajaran pada institusi atau lembaga resmi di bidang pendidikan. Pendidikan informal dapat diperoleh melalui pendidikan di dalam keluarga maupun lingkungan. Dalam pelaksanaan pendidikan informal, kondisi lingkungan maupun keluarga menjadi salah satu faktor yang sangat berpengaruh terhadap keberhasilannya. Dalam menunjang keberhasilan pendidikan ini sangat diperlukan kondisi atau suasana yang menggambarkan kenyamanan, keamanan, kesejahteraan dan beberapa hal lainnya yang dapat membangkitkan nilai positif dalam diri anak sebagai sesorang yang sedang menjalani proses pendidikan.

Namun kenyataan sering sekali berbeda dari apa yang diharapkan. Kondisi lingkungan yang tadinya diharapkan mendukung berlangsungnya proses pembelajaran untuk tujuan pencapaian pendidikan justru mempertontonkan hal yang sebaliknya, di 
mana kondisi yang kerap sekali terjadi justru menimbulkan ketidaknyamanan, ketidakamanan, rasa mencekam, ketakutan, intimidasi dan masih banyak hal lainnya. Salah satu praktik yang terjadi di lingkungan di mana para generasi muda khususnya anak berada adalah tindakan kekerasan baik secara fisik maupun nonfisik. Kekerasan ini terjadi bukan hanya kepada Anak, namun juga kepada sosok yang paling dekat dan paling berperan penting dalam proses tumbuh kembang anak yaitu kaum lbu ataupun perempuan pada umumnya yang bagi sebagian orang dianggap menjadi kaum yang lemah.

Berdasarkan Catatan Tahunan (CATAHU) Komnas Perempuan Tahun 2020 yang diluncurkan pada tanggal 6 Maret 2020 disampaikan bahwa kasus kekerasan yang dilaporkan mengalami peningkatan yang sangat signifikan dalam kurun waktu lima tahun terakhir. Tercatat 431.471 kasus kekerasan terhadap perempuan, di mana sebanyak 421.752 kasus bersumber dari data yang ditangani oleh Pengadilan Agama, 14.719 kasus yang bersumber dari data yang ditangani oleh lembaga mitra pengadalayanan di tingkat provinsi, 1419 kasus dari Unit Pelayanan dan Rujukan (UPR), yaitu unit yang sengaja dibentuk oleh Komnas Perempuan. Kekerasan terhadapa perempuan dan anak dianalogikan sebagai peristiwa fenomena gunung es, di mana sesungguhnya masih banyak kasus yang belum terungkap di permukaan namun pada dasarnya terjadi dan dialami oleh kaum perempuan dan juga anak. (Perempuan, K., 2020).
Berbagai upaya penghapusan kekerasan terhadap perempuan dan anak sesungguhnya telah dilakukan oleh pemerintah, mulai dari pengaturan dasar hukum yang jelas terhadap pemberian sanksi terhadap pelaku tindak kekerasan terhadap perempuan dan anak yang diatur dalam Undang-undang Nomor 23 Tahun 2002 sebagaimana telah diubah dengan Undang-undang Nomor 35 Tahun 2014. Namun lagi-lagi dasar hukum yang kuat jika tidak diimbangi dengan kesadaran etis aparat penegak hukum dalam pemberlakuannya ternyata tidak memberikan dampak apa-apa terhadap pengurangan bahkan penghapusan tindakan kekerasan terhadap perempuan dan anak. (Taufiq, T., 2020).

Selain penentuan dasar hukum yang kuat serta penegakannya, pemerintah melalui program sinergitas mulai dari tingkat pusat maupun daerah dengan berbagai elemen masyarakat yang tergabung dalam organisasi lembaga keagamaan maupun lembaga sosial masyarakat lainnya, bahkan dengan perguruan tinggi sebagai lembaga akademisi. Berbagai program sinegitas yang dilakukan mulai dari yang sifatnya sebagai hulu (sumbersumber pemicu terjadinya kekerasan) sampai ke hilir (penanganan korban kekerasan). Salah satu bentuk upaya pemerintah melalui sosialisasi terkait kekerasan dan pencegahan terjadinya kekerasan di lingkungan masyarakat.

Pemerintah Provinsi DKI Jakarta turut aktif dan partisipatif dalam melakukan penanganan terhadap pencegahan kekerasan terhadap perempuan dan anak, salah satunya melalui 
Dinas Pemberdayaan, Perlindungan Anak dan Pengendalian Penduduk (DPPAPP). Melalui program sinergitas bersama dengan berbagai Lembaga Masyarakat dan juga Perguruan Tinggi, DPPAPP menjalin kerjasama yang dilegalkan dalam bentuk Perjanjian Kerjasama (PKS) dengan beberapa perguruan tinggi termasuk di antaranya Universitas Kristen Indonesia, Jakarta.

Implementasi dari kerjasama salah satunya dalam bentuk Pengabdian kepada Masyarakat (PkM) berupa sosialisasi atau penyuluhan tentang berbagai hal yang dipandang menjadi permasalahan di masyarakat, salah satunya adalah terkait pencegahan kekerasan terhadap perempuan dan anak. Kegiatan PkM ini dilaksanakan dalam rangka kampanye 16 hari anti kekerasan terhadap perempuan dan anak dengan sub topik yang divariasikan namun tetap terkait dengan upaya pencehagan kekerasan terhadap perempuan dan anak.

\section{METODE}

Metode pelaksanaan pengabdian kepada masyarakat ini dilakukan dalam bentuk penyuluhan atau sosialisasi yang bertujuan untuk memberikan pemahaman serta kesadaran kepada seluruh stakeholder tentang betapa perlunya tindakan nyata dalam melakukan pencegahan kekerasan terhadap perempuan dan anak.

Penyuluhan atau sosialisasi dilaksanakan secara virtual atau online dengan menggunakan zoom meeting, yang juga ditayangkan secara live streaming melalui akun youtube channel DPPAPP DKI Jakarta. Pelaksanaan sosialisasi virtual divariasikan dalam bentuk webinar dan juga talkshow.

Untuk setiap sesi UKI bermitra dengan perguruan tinggi lainnya seperti: UHAMKA, STIE IPWIJA, UNIKA Atmajaya, juga Kominfotik DKI Jakarta dan P2TP2A, dengan pembagian tugas baik sebagai narasumber dan juga moderator.

Dalam kegiatan PkM ini, UKI mengambil bagian untuk empat topik dengan daftar sebagaimana dalam tabel 1 berikut:

Tabel 1. Daftar Topik dan Narasumber PkM

\begin{tabular}{rll}
\hline No. & \multicolumn{1}{c}{ Topik } & \multicolumn{1}{c}{ Narasumber dari UKI } \\
\hline 1. & Pembelajaran Jarak Jauh, enjoy aja!! & Dr. dr. Bernadetha Nadeak, M.Pd \\
2. & Pencegahan Kekerasan di Tempat Publik & Mita Yesyca, M.Sc \\
3. & Cerdas Bermedia Sosial & Juitan Lase, M.Ikom \\
4. & Stop Trafickking Tugas Kita Semua & Dr. Mompang L. Panggabean, M.H \\
\hline
\end{tabular}

Sebelum pelaksanaan kegiatan, dan tanggungjawab DPPAPP. Flyer didesain penyiapan flyer, penyediaan zoom meeting dengan mencantumkan logo tiap perguruan dan mengundang peserta merupakan tugas tinggi atau lembaga masyarakat yang bermitra 
dan juga logo Jaya Raya. Adapun flyer yang disiapkan sebagaimana dalam kompilasi gambar 1 berikut:
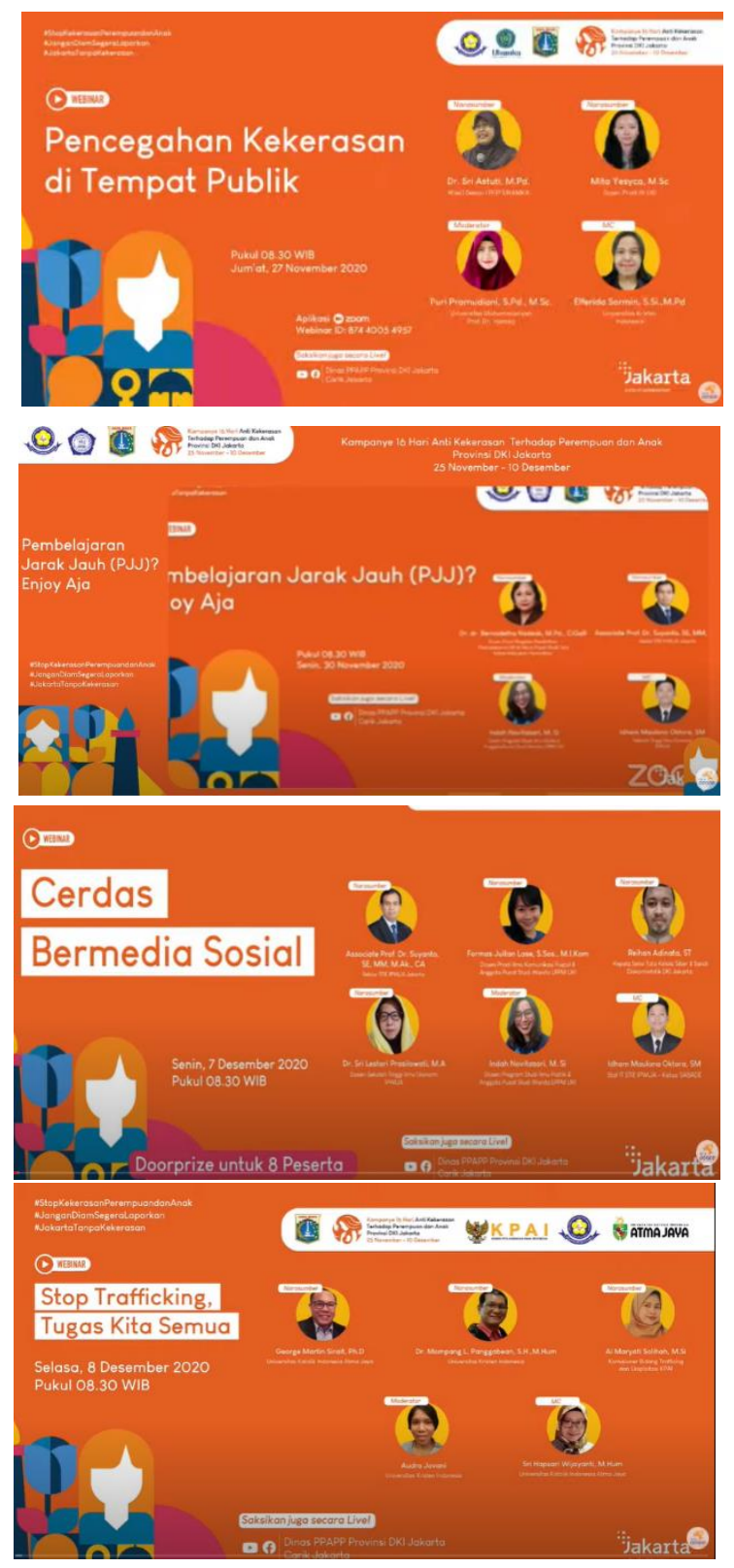

Gambar 1. Flyer Kegiatan

\section{HASIL DAN PEMBAHASAN}

Kegiatan pengabdian kepada masyarakat dalam rangka kampanye 16 hari anti kekerasan terhadap perempuan dan anak diselenggarakan selama 16 hari yang dikelola oleh DPPAPP bersama berbagai lembaga mastarakat dan juga perguruan tinggi.

Universitas Kristen Indonesia mengambil bagian dalam empat sesi dengan empat topik yang berbeda, antara lain:

\section{Pencegahan Kekerasan di Tempat Publik}

Penyuluhan tentang pencegahan kekerasan di tempat publik dilaksanakan pada tanggal 27 November 2020. UKI bermitra dengan UHAMKA menghadirkan narasumber dari UKI yaitu: Mita Yesyca. M.Sc dan MC yaitu Elferida Sormin, S.Si., M.Pd serta satu narasumber lainnya beserta moderator dari UHAMKA. Pada penyuluhan sesi ini, yang menjadi peserta adalah para kader dan ibuibu PKK serta dari P2TP2A, OPD yang berada di wilayah pemerintahan DKI Jakarta. Dalam paparan para narasumber dijelaskan fakta bahwa frekuensi kekerasan yang dialami oleh perempuan dan anak di tempat publik sangatlah tinggi, seperti halnya dalam fasilitas pengangkutan umum seperti commuter line, bus way, Angkutan Kota dan fasilitas transportasi lainnya.

Perempuan dan anak yang menjadi korban kekerasan dikategorikan ke dalam tiga opsi yaitu: 1) Tidak menyadari bahwa tindakan yang dialami merupakan tindakan kekerasan, sehingga cenderung melakukan pembiaran dan berlalu begitu saja. Kecenderungan ini dapat menimbulkan efek pelaku semakin merajalela karena perlakuannya dianggap lepas dari pemantauan karena tidak pernah mendapat komplain atau keberatan dari korban yang bersangkutan atau bahkan pelaku juga akan merasa dirinya tidak sedang 
berbuat sesuatu yang salah, sehingga cenderung akan melakukan hal yang sama kepada orang lain. 2) Korban merasakan tindakan kekerasan, namun tidak melakukan tindakan apa-apa diakibatkan oleh rasa takut dan terancam. Kecenderungan ini bisa diakibatkan oleh rasa takut dibarengi rasa malu, namun juga banyak yang oleh karena terancam dan tidak mengetahui harus melakukan apa?. Ketidakpahaman akan tindakan apa yang harus dilakukan ketika mendapat perlakukan tindakan kekerasan, termasuk tidak mengetahui pos pengaduan terkait penenganan tindakan kekerasan menjadi pemicu utama timbulnya rasa takut pada diri si korban. 3) Sesorang yang mengalami tindakan kekerasan dan merasa terancam segera mengambil tindakan. Tindakan yang dilakukan bisa dalam bentuk perlawanan jika sanggup melakukan, atau lebih dianjurkan untuk melaporkan kepada pihak-pihak terkait yang secara resmi menjadi tempat pengaduan untuk selanjutnya dapat memberi pertolongan atau penanganan.

Pada Sesi ini para peserta sangat antusias mengikuti dan secara aktif berdiskusi dengan mengajukan banyak pertanyaan, di antaranya adalah bagaimana cara seorang perempuan sebagai seorang istri yang mengalami kekerasan dalam rumah tangga dapat melepaskan diri dari tindakan tersebut tanpa harus merusak ikatan pernikahan; apakah ada tempat pengaduan yang aman bagi seorang perempuan atau anak yang mengalami tindakan kekerasan?; apakah tindakan kekerasan lebih dominan diakibatkan oleh faktor internal korban ataukah dari faktor eksternal yaitu si pelaku?; Bagaimana tips and trik mengurangi terjadinya kekerasan dalam rumah tangga?; dan masih banyak pertanyaan lainnya. Jawaban atas pertanyaan-pertanyaan tersebut disampaikan oleh para narasumber dengan sangat jelas dan dibantu oleh DPPAPP untuk hal-hal yang sifatnya menyangkut kebijakan pemerintah dalam penanganan tindakan kekerasan terhadap perempuan dan anak.

\section{Pembelajaran Jarak Jauh, Enjoy Aja}

Sosialisasi tentang pembelajaran jarak jauh, enjoy aja, dilaksanakan pada tanggal 30 November 2021 dengan narasumber dari UKI adalah Dr. dr. Bermadetha Nadeak, M.Pd. dan moderator Indah Novitasari, M.Si beserta narasumber dari STIE IPWIJA sebagai mitra UKI yang dipercayakan oleh DPPAPP.

Pembelajaran pada masa pandemi Covid-19 yang mengharuskan pelaksanaanya secara daring tidak hanya menimbulkan kepanikan baru di kalangan para siswa, namun juga berdampak bagi para orangtua di rumah, di mana peran orangtua menjadi lebih dominan untuk memastikan anak-anak mengikuti pembelajaran daring dengan baik. Anak menjadi lebih banyak di rumah dan menyelesaikan berbagai tugas sekolah dari rumah, hal ini kerap sekali membuat orangtua merasa tidak mampu dan cenderung stres sehingga tidak sedikit yang berujung pada tindakan kekerasan terhadap anak itu sendiri. Beberapa kasus yang terjadi seperti terjadinya tindakan kekerasan orangtua terhadap anak usia sekolah dasar yang oleh karena dianggap tidak bisa mengikuti 
pembelajaran dengan baik sampai berujung pada kematian si anak.

Selain ketidakmampuan orangtua dalam melakukan pendampingan terhadap anak yang melakukan pembelajaran secara daring, adanya keterpurukan ekonomi akibat adanya pemutusan hubungan kerja yang dianggap berdampak pada ketidakmampuan mencukupi pemenuhan fasilitas pembelajaran online, seperti pengadaan gadget, pengadaan kuota internet dan yang lainnya dalam menunjang pembelajaran online juga merupakan penyebab tingginya tingkat stres orangtua yang pada akhirnya juga berujung pada tindakan kekerasan terhadap anak.

Pada sesi ini para peserta juga sangat antusias dan rata-rata mengaku mengalami hal yang sama. Namun pada sesi ini dilakukan variasi kegiatan, yakni selain sosialisasi oleh para narasumber, juga diadakan sharing antar peserta, sehingga diperoleh sharing pengalaman yang berbedabeda, di mana ternyata tidak sedikit juga peserta yang mengaku awalnya kesulitan dalam mendampingi anak melakukan pembeajaran secara online, namun setelah melakukan beberapa hal akhirnya kesulitan bisa diatasi. Bahkan dari peserta ada yang menyampaikan bahwa dilingkungan mereka dilakukan upaya bakti sosial berupa urunan dana dari warga dalam upaya pengadaan jaringan internet, sehingga dapat digunakan oleh anak-anak sekolah di lingkungan RT/RW tersebut.

\section{Cerdas Bermedia Sosial}

Topik tentang Cerdas Bermedia Sosial dilaksanakan pada tanggal 7 Desember 2021 dengan narasumber dari UKI yaitu: Formas Juitan Lase, M.lkom dan moderator Indah Novitasari, M.Si dan dua narasumber lainnya dari STIE IPWIJA dan Kominfotik DKI Jakarta. Media sosial yang seharusnya digunakan sebagai sarana untuk mengembangkan diri, menambah wawasan, menebarkan kebaikan, mempublikasikan hal-hal baik dan menarik dari hasil karya seseorang untuk diketahui oranglain dan selanjutnya bermanfaat, acapkali terjadi sebaliknya, di mana media sosial sering menjadi pemicu terjadinya tindakan kekerasan terhadap perempuan dan anak. Tidak sedikit kasus kekerasan yang dialami oleh perempuan dan anak bermula dari media sosial, di mana seorang perempuan memposting foto dalam akun media sosialnya kemudian lewat aun tersebut berkenalan dengan seorang pria, selanjutnya janji bertemu dan berujung pada tindakan kriminal seperti pemerasan, perkosaan bahkan pembunuhan. Tindakan-tindakan mengunggah ujaran kebencian, menyebarkan berita hoaks, memposting kegiatan-kegiatan pribadi yang sesungguhnya orang lain tidak perlu mengetahui seringkali menjadi pemancing terjadinya keributan bahkan menimbulkan niat-niat jahat bagi orang yang mengintai dan siap memangsa korban.

Kebijaksanaan dan kecerdasan dalam menggunakan media sosial menjadi hal yang mutlak bagi setiap orang di era yang serba digital ini. Pengguna media sosial diharapkan menjadi tuan bagi media sosialnya, bukan 
sebaliknya malah menjadi budak yang diperhamba oleh karena adanya rasa ketagihan atau addiksi sehingga tidak bisa mengendalikan diri yang berujung kepada hal-hal yang tidak diinginkan.

\section{Stop Trafficking, Tugas Kita Semua}

Trafficking merupakan satu tindakan nyata bentuk kekerasan terhadap perempuan dan anak yang dilakukan oleh sekelompok orang baik teroganisisr maupun tidak. Sesi paparan tentang Stop Trafficking, Tugas Kita Semua dilaksanakan pada tanggal 8 Desember 2021 dengan narasumber Dr. Mompang $L$. Panggabean, S.H., M.H. dan moderator Dr. Audra Jovanni, serta dua narasumber lainnya dari Universitas Katolik Atmajaya.

Tidak sedikit kasus tentang perdagangan manusia secara khusus perempuan terjadi di Indonesia. Berkedok sebagai calon Tenaga Kerja Indonesia (TKI) atau Tenaga Kerja Wanita (TKW), sering sekali membuat para perempuan tertipu dan dengan mudahnya mengikuti semua kemauan seseorang atau sekelompok orang yang mengaku diri sebagai agen. Namun kenyataannya, bukan pekerjaan yang halal yang mereka dapatkan, akan tetapi sebagian ada yang diperkerjakan sebagai pekerja seks, istri kontrakan, bahkan yang paling ekstrim untuk kasus anak, ada yang menjadi budak pemuas nafsu orangorang yang memiliki penyimpangan seksual seperti pedofilia dan sejenisnya.

Dalam diskusi ini para narasumber memamparkan dengan sangat jelas aturan perundang-undangan yang sudah ditetapkan dan diberlakukan di Indonesia yang sesungguhnya sudah sangat tegas menjelaskan hukuman bagi orang-orang yang bertindak sebagai pelaku perdagangan orang/trafficking. Selain itu dalam sesi diskusi juga disampaikan bahwa sangat diharapkan keperdulian bersama dari semua stakeholder dalam upaya pencegahan terjadinya trafficking ini. Waspada menjadi satu kata yang harus selalu dipraktikkan sebagai salah satu langkah menghentikan praktik perdagangan orang/trafficking.

Dari empat sesi dengan topik yang berbeda namun memiliki keterkaitan dengan upaya mengakhiri kekerasan terhadap perempuan dan anak, semuanya berlangsung sangat efektif dan efisien. Antusiasme peserta dalam mengikuti setiap sesi sangat tinggi yang dapat dilihat dari jumlah peserta yang mengikuti dari awal sampai akhir untuk zoom meeting hampir mencapai 500 orang. Jika digabung dengan peserta yang menyaksikan lewat youtube streaming DPPAPP, Media sosial DPPAPP seperti Facebook dan Instagram, untuk setiap sesi rata-rata diikuti oleh 20.000 viewer.

Berbagai komentar positif dari peserta tentang kegiatan sosialisasi ini semkain menambah catatan bahwa kegiatan ini sangat bermanfaat bagi masyarakat karena memberikan informasi yang jelas tentang apa dan bagaimana itu kekerasan terhadap perempuan dan anak, serta langkah-langkah pencegahan yang dapat dilakukan.

\section{SIMPULAN}

Kegiatan pengabdian kepada masyarakat UKI bersama DPPAPP dan berbagai 
universitas di DKI Jakarta dalam rangka kampanye 16 Hari Anti Kekerasan Terhadap Perempuan dan Anak dengan peserta terdiri dari para kader, PKK, organisasi perempuan, organisasi keagamaan dan yang lainnya, yang dilaksanakan secara daring dipandang sangat efektif dalam memberikan edukasi dan informasi tentang apa dan bagaimana itu kekerasan terhadap perempuan dan anak serta langkah-langkah penangannya atau pencegahannya. Pencegahan tindakan kekerasan terhadap perempuan dan anak tidak dapat dilakukan oleh satu pihak saja, namun harus dilakukan secara bersinergi oleh semua stakeholder di masyarakat.

\section{UCAPAN TERIMA KASIH}

Ucapan terimakasih kepada

1. Pemprov DKI Jakarta yang telah menjalin kerjasama dengan UKI

2. DPPAPP DKI Jakarta yang telah menjadi mitra yang baik dan kooperatif dalam pelaksanaan kegiatan pengabdian kepada masyarakat

3. Pimpinan Universitas Kristen Indonesia yang dengan terbuka mendukung pelaksanaan kegiatan ini sebagai wujud implementasi salah satu dari tiga dharma perguruan tinggi

4. Berbagai universitas yang menjadi mitra UKI dalam pelaksanaan kegiatan PkM

\section{REFERENSI}

Suryamizon, A. L. (2017). Perlindungan Hukum Preventif Terhadap Kekerasan Perempuan dan Anak Dalam Perspektif Hukum Hak Asasi
Manusia. Marwah: Jurnal Perempuan, Agama dan Jender, 16(2), 112-126.

Perempuan, K. (2020). Kekerasan meningkat: Kebijakan penghapusan kekerasan seksual untuk membangun ruang aman bagi perempuan dan anak perempuan. Catahu: Catatan tahunan tentang kekerasan terhadap perempuan, 1-109.

Taufiq, T. (2020). Sanksi Hukum Terhadap Pelaku Tindak Kekerasan Terhadap Perempuan dan Anak. Pena Justisia: Media Komunikasi dan Kajian Hukum, 19(1).

Nadeak, B., Naibaho, L., Sunarto, S., Tyas, E. H., \& Sormin, E. (2021). Learning Management in Suburban Schools During the Midst of COVID19. Psychology and Education Journal, 58(2), 1131-1139.

Tyas, E. H., Sunarto, L. N., Nadeak, B., \& Sormin, E. (2021). Lecturers' Cultural Sensitivity on Using Social MediaFacebook and Instagram. Psychology and Education Journal, 58(2), 59745980.

Nadeak, B., Sormin, E., Naibaho, L., \& Deliviana, E. (2020). Sexuality in Education Begins in The Home (Pendidikan Seksual Berawal Dalam Keluarga). Jurnal

Comunita Servizio, 2(1), 254-264.

Arifudin, O., Hidana, R., Julius, A., Doho, D. B., Sormin, E., Ghazali, A., ... \& Bahri, A. S. (2020). Psikologi Pendidikan (Tinjauan Teori Dan Praktis).

Nadeak, B., Deliviana, E., Sormin, E., Naibaho, L., \& Juwita, C. P. (2019). Pembinaan Ketahanan Pernikahan dan Keharmonisan Keluarga Dengan Tema "The Family Relationship and Intimacy. Jurnal ComunitÃ Servizio: Jurnal Terkait Kegiatan Pengabdian kepada Masyarakat, terkhusus bidang Teknologi, Kewirausahaan dan Sosial Kemasyarakatan, 1(2), 179-185.

Purba, L. S. L., Sormin, E., \& Harefa, N. (2019). Effectiveness of use of online games kahoot! chemical to improve 
student learning motivation. Jurnal Pendidikan Kimia, 11(2), 57-66.

Sihotang, H., Nadeak, B., \& Siregar, R. (2020). Penerapan Belajar Mandiri dengan Strategi Efektif pada Masa Pandemi Covid-19 Bagi Remaja HKBP Duren Jaya Bekasi. JURNAL ComunitÃ Servizio: Jurnal Terkait Kegiatan Pengabdian kepada Masyarakat, terkhusus bidang Teknologi, Kewirausahaan dan Sosial Kemasyarakatan, 2(2), 393-405.

Sianipar, D., Rambitan, S., Sairwona, W., \& Zega, Y. K. (2020). PELATIHAN PENGGUNAAN METODE MENGAJAR REMAJA DI MASA PANDEMI COVID-19 DI HKBP
RESORT

JATISAMPURNA

BEKASI. JURNAL ComunitÃ Servizio: Jurnal Terkait Kegiatan Pengabdian kepada Masyarakat, terkhusus bidang Teknologi, Kewirausahaan dan Sosial Kemasyarakatan, 2(2), 406-428.

Putri, S. Y., Astuti, W. R. D., \& Situmeang, N. (2020). PELATIHAN PENGGUNAAN SOSIAL MEDIA UNTUK MENGEMBANGKAN AKSES PASAR BAGI UMKM KABUPATEN SERANG. JURNAL Comunit á Servizio: Jurnal Terkait Kegiatan Pengabdian kepada Masyarakat, terkhusus bidang Teknologi, Kewirausahaan dan Sosial Kemasyarakatan, 2(2), 437-446. 